\title{
Managers in Polish Organizations - the Results of Empirical Research
}

\author{
Dr Izabela Bednarska-Wnuk \\ Faculty of Management, Uniwersity of Lodz, Poland
}

\begin{abstract}
Today we are dealing with unceasing changes that are not without influence on the functioning of the organization and its subsystems; and managers, who are specific moderators of all activities in the organization, in the face of the volatility of the environment, need to acquire new competences and roles, and realize relevant functions. It seems that the manager's role may be dependent on organizational characteristics such as the type of organization (for-profit, non-profit), the industry in which the organization operates and its size. These features can determine the roles and functions of the persons responsible for the management of organizations. Taking this into account, the aim of this article is to present the role of managers in Polish organizations, depending on their industry and size based on the results of empirical research. The study was conducted in 2015 among 289 organizations in Poland. One of their objectives was to identify a modern role of managers, depending on the selected organizational features based on interviews with people responsible for personnel policy in these organizations. Studies have shown that the role of the manager and basically just its scope is dependent on the size of the organization. On the other hand, no relationship between the role and the industry in which the organization operates has been observed.
\end{abstract}

Keywords: the role of a modern manager, organizational behaviour, Poland

\section{Introduction}

In the modern world we deal with unceasing changes that are not without influence on the functioning of the organization and its subsystems; and managers, who are specific regulators of all activities in the organization, in the face of the volatility of the environment need to acquire new competences, and roles, and realize the relevant functions. Their role alongside social role is crucial in the description of the functioning of the organization. It plays a key role in the analysis of organizational behaviour. Considerations about the manager are usually analyzed from the perspective of a set of various requirements and expectations placed upon the role of management. This role under the influence of the changes in the environment is also subject to variation. We can discern the evolution of the manager's role. It seems that the role of the manager may also be constituted, depending on the organizational features such as the type of organization (for-profit, non-profit), the industry in which the organization operates and its size. These features can determine the roles and functions of the persons responsible for the management of organizations. Taking this into consideration, the purpose of this article is to present the role of managers in Polish organizations, depending on their industry and size based on the results of empirical research. Given its purpose, the article first discusses the role of a manager in the organization, and then shows the importance of the size of the organization and its industry for efficient management. Further, it presents the results of research conducted in 2015 among 297 organizations in Poland ${ }^{1}$. They are designed to indicate the contemporary role of managers depending on the selected organizational features based on interviews with people responsible for personnel policy in these organizations.

\section{The modern manager in the organization - theoretical assumptions}

\footnotetext{
1 The Project was financed from the means of the National Science Centre granted on the basis of decision No DEC2013/09/B/HS4/02722.
} 
The literature on the role of a modern manager in the organization is very rich (Mair, Thurner, 2008 Rouleau, Balogun 2011, C. Desmarais, Abord de Chatillon 2010). This is due to the fact that the concept of manager is given different meanings, at the same time rarely emphasizing their differences. The term 'manager' both in ordinary speech and in the literature on management is used in a broad sense. Manager may therefore be each person considered to be managing the organization or its separate part, no matter what place they occupy in the organizational hierarchy. This means that the term 'manager' is used with reference to the director, manager, supervisor or superior (Ornarowicz 2008).

The role of the manager is usually described in the organization and is characterized by a diverse structure. This is due to various requirements placed upon managers, related to the objectives pursued and tasks in the organization and the numerous interactions between the manager and the other stakeholders of the organization. It is also related to the fact that since the beginning of the development of the science of organization and management, numerous discussions have been undertaken related to the functioning of executives in the organization. Since that time there have appeared a number of typologies describing the role of leader and various sets of requirements. They are consistent with the nomenclature of currently functioning schools or trends in management as well as with given conditions of the organization's environment. It can therefore be pointed out that the role of management and its scope changes over the years, being of interest to many theorists and practitioners in the field of management, sociology or psychology (Mintzberg 1980, Willmott 1987, D Katz, RL Kahn 1966, Ayache, Laroche 2010).

Initially (the turn of XIX / XX) the manager's role was identified with the coordination of activities, extensive control apparatus, administration and organization of work for subordinates. The superior was always placed in the centre of the action. In terms of the time horizon of playing leadership roles, the manager realized them in a permanent manner. He also did not hold the other roles in the organization, beyond those specific ones assigned to a particular position. This means that the organization employed the manager practically 'for life', usually for an indefinite period (Bednarska-Wnuk 2016 p.134). Whereas according to the $\mathrm{M}$. Jablonski, the range of functions realized by the manager in the classic organization extended well beyond the realization of managerial function and tasks of the modern manager. In particular, the functions of the manager towards the organization and subordinates included: taking care of the image of the organization, honesty and willingness to act for the good of the managed institution, "moral care" to promote "local office patriotism" (and according to modern nomenclature, loyalty and trust of employees), and staff management ( Jablonski 2012, p. 27).

Today, however, we observe the change in managerial positions in terms of tasks, image and values. It is noticed in the activities of various business organizations that they move away from the traditional image of the boss as the best specialist in the group of employees, or the boss who is an efficient administrator, towards the role of managers as the rotary project managers, integrators (coordinators) of the operations of network organizations or virtual teams, knowledge managers or high-tech managers (Lachiewicz 2013, p.5). Contemporary managers today are attributed to many different, very advantageous characteristics, both tangible (e.g. education, work experience, vocational training, etc.) and intangible (knowledge of the psycho-social problems, the ability to win people over, knowledge and skills in negotiation etc.). Of crucial importance are also the innate character and special abilities (Nogalski, Śniadecki 2001 p.92).

The approach to organizational power changes too. Today, relations become more democratic. This means making decisions on the basis of joint consultation with subordinates, while the proviso that the final decision belongs, however, to the manager. The relations between superiors and subordinates are based on mutual trust, which affects the decisionmaking process. Power distance is small. The role of the manager here boils down not only to fulfilling specific management roles and implementation of managerial functions, but also to creating such a work environment that provides subordinates with autonomy and freedom of action. In terms of the time horizon, performing modern management roles is characterized by temporality. This means that the completion of a specific task is followed by a "transfer" of power to another person designated by the manager. The manager, although he has a clearly defined role associated with the managerial work, in practice performs in the organization many other roles within the scope of other jobs (Bednarska-Wnuk 2016, p. 134). There is also noted a tendency to hiring managers primarily in Poland, usually for a specified period and based on the management contract. But it has no regulations in the Polish Labour Code, only in the Civil Code, which in addition to the agreements referred to in the regulations, allows for entering unnamed service contracts. It is a form of hiring managers, which today is becoming increasingly popular among experienced managers, not only in Poland but all over the world (http://www.hrpolska.pl/kadry/narzedzia/najemnicy-korporacji-kontrakt-na-zarzadzanie). 


\section{Selected characteristics of the organization and the role of manager}

Efficient and effective execution of the role of manager in the organization depends on many factors, resulting from internal and external conditions. They may also be examined from the perspective of both the individual and the organization. With regard to individual conditioning, today we have a lot of studies in this field, which emphasize different attributes of a manager in the organization (Akella 2006, Stosik 2005, Rakowska 2007, Nogalski, Śniadecki 2001). There are slightly fewer examples in the literature showing the role of manager, depending on the organizational features that highlight the different ways of organization management. For example, execution of manager functions may be implemented differently in a small business and otherwise in a large enterprise. This is mainly due to factors such as: configuration, formalization, standardization and centralization, which make up the structure of the organization. With regard to the description of the role of the manager in the organization, it seems that the symptomatic features describing the organization ${ }^{1}$ include:

- The size of the organization;

- Industry in which the organization operates;

- The shape of the organizational structure.

The first feature, which is the size of the organization, categorizes companies into four groups: a micro-enterprise which employs fewer than 10 employees; small enterprise that employs fewer than 50 employees; medium-sized enterprise employing fewer than 250 employees and a large enterprise, employing 250 workers and over [http://archiwum.parp.gov.pl/dotacjedoc/def_msp.pdf ; access: 18.08.2016). It should be noted, however, that micro, small and medium-sized enterprises, the so-called SMEs have the largest percentage in the structure of the Polish economy and a large share of this sector in the development of Gross Domestic Product.

However, it should be noted that categorization of enterprises by the volume of employment takes into account only those employed under a contract of employment. In many cases, this may not represent the actual scale of employment. This is a problem of statistical categorization, which may make it difficult to analyze many processes in the cross-section of employment volume [Bak-Grabowska 2016 p.117]. Differences in the management of the organizations of all sizes consists mainly in a different approach to the implementation of the functions of management and a concentration on the critical resources of the organization. Large companies usually have more opportunities to compete, have diverse resources at their disposal, and may embrace a greater range of activity than, for example, micro-enterprises. All this also creates other conditions to perform management roles, which causes that their catalogue may significantly differ.

In turn, the industry or the core business of the organization can also significantly influence the decisions of the managers and their role. Industry, and basically its specificity, may in fact determine the different character of supervising the work, which, depending on its type may require from supervisors a typical formal relation to subordinates, or may be based on partner relations.

The last separated feature is the shape of an organizational structure. It contains all the structure-forming elements that affect implementation of the role of the manager in the organization. We can, therefore, list here elements such as: size of the structure, the degree of specialization, centralization, formalization and standardization [Bielski 2002 p.105]. All these dimensions may permeate one another to form various configurations. It should be emphasized that, although the size of the organization is one of the dimensions of the structure, it was decided to purposely separate this element, thus giving it significance during the effective execution of management roles. This procedure allowed for differentiation of organizations, depending on employment, and focusing only on this variable. It seems that the discussed selected features of the organization may significantly affect the role of the manager, its makeup or the scope of organization power.

\section{Research Methodology}

In order to determine the characteristics of the modern manager the author used research results coming from the research project entitled "Wielowymiarowa Analiza Zachowań Organizacyjnych [WAZO] - Metodyka i narzędzia pomiaru."2 According to the assumptions in the project, empirical research was conducted in two stages. The aim of the first stage

\footnotetext{
${ }^{1}$ The size and industry of the organization are the qualities that have been identified in this project .The size of the organizational structure were not analyzed, as it did not fall within the scope of this study.

2 Description of the research methodology comes from K. Januszkiewicz (ed.), Wielowymiarowa Analiza Zachowań Organizacyjnych [WAZO] w polskich przedsiębiorstwach. Wyniki badań empirycznych, Wydawnictwo Uniwersytetu Łódzkiego, Łódź 2016, p. 9-17 (In printing)
} 
was the description of the organization, the second objective - description of organizational behaviour of employees in the organizations selected deliberately from the first stage. The research was carried out in 2015.

The results presented in the article are from the first stage, in which the study was aimed at for-profit companies operating on Polish territory, employing at least 50 employees. The tool used in the process of research was the original questionnaire - developed by the team constituting the project. It consisted of two parts. The first part concerned the organizational solutions and allowed for their diagnosis for the organization as a whole and for individual dimensions studied (organization of work, superior-subordinate relations, employee-organization relations, organizational culture, personnel policy, communication). The second part referred, instead, to organizational behaviour, and in turn enabled the diagnosis in global terms for the employee as well as against the individual dimensions (mentioned above).

At the first stage, the questionnaire was addressed to those responsible for personnel policy in the company (director of $\mathrm{HR}$ or appropriate department for the management of human resources in the company; in the case of organizations without $\mathrm{HR}$, the study involved the owner or director of the company).

In the first stage of the study, therefore, a contact was made with more than 12000 companies that met the eligibility criteria for the study. Effectively, 289 interviews were completed with people responsible for HR policy from various organizations, receiving initial approval to join the second phase of the study.

To increase participation of respondents, it was agreed to conduct the survey questionnaire in the form of an interview. Participants were those responsible for personnel policy in the company. Two methods were used:

- Computer-assisted telephone interviews (CATI)

- self-completing online interviews (CAWI)

Contact method was adapted to the preferences of the respondent. The questionnaire was designed according to the mix mode method, allowing obtaining comparable results regardless of the method of contact. Both modes contained the adopted solution of thematic rotation in order to avoid the effect of freshness and the effect of fatigue.

In the sample $71.6 \%$ were companies employing 50 to 249 employees (defined in the study as medium), while $26.3 \%$ were companies employing over 250 employees (defined in the study as big). In the case of $2.1 \%$ of companies the data on the volume of employment have not been obtained. $42.8 \%$ of companies represented the service industry, $40.9 \%$ - the manufacturing industry, and $15.9 \%$ were companies belonging to the retail industry.

Industry structure of large enterprises differs distinctly from the medium ones. Among medium-sized enterprises prevail service firms $(50 \%)$, while among large - the manufacturing ones $(60.5 \%)$. However, the share of trading companies is similar in both groups (approx. 16\%).

For the purposes of this article, the aim of the study was defined as an attempt to answer the question whether the role of the manager in an organization is dependent on features such as the industry in which the organization operates and its size. On this basis, we formulated the following hypothesis:

$\mathrm{H}$ : It can be assumed that the role of the manager in an organization is dependent on the industry in which the organization operates and its size.

In the course of the research process, the following research questions were posed:

- What form of employment characterizes a modern manager?

- What is the scope of the role in a managerial position?

- Who and to what extent shall decide on the method of performance and the pace of work of subordinates? 
In designing the study it was assumed that the independent variables that adopted the status of the explanatory variables are the industry and the size of the organization. When determining the dependencies and checking the hypothesis the chisquare test was used with the Pearson correlation coefficient under the assumed level of $\alpha=0.05$.

\section{The results of empirical research}

When analyzing the results on the characteristics of the modern manager it should be noted that in Polish organizations managers are employed primarily for an indefinite period. Such a response accounts for more than $2 / 3$ of indications $(81.3 \%)$. However, $13.7 \%$ of respondents indicated that managers are hired on a temporary basis. Only $4.9 \%$ are employed on the basis of management contract.

Depending on the characteristics of the organization (industry and employment volume) it is noted that there is no relationship between these variables and the type of employment of managerial staff in the organization; respectively for industry $p=0.691$ and the volume of employment $p=0.302$. The results show that the characteristics of the organization do not affect the type of employment of managerial staff. This is shown in Table 1.

Table 1 Type of employment of executives against industry and employment volume

\begin{tabular}{|c|c|c|c|c|c|}
\hline \multirow{2}{*}{$\begin{array}{l}\text { Type of employment of } \\
\text { managerial staff }\end{array}$} & \multicolumn{3}{|c|}{ Industry $(p=0.691)$} & \multicolumn{2}{|c|}{$\begin{array}{l}\text { Employment volume } \\
(p=0.302)\end{array}$} \\
\hline & Commerce & $\begin{array}{l}\text { Production, } \\
\text { industry }\end{array}$ & Services & $50-250$ persons & $\begin{array}{l}\text { Over } \\
250 \text { persons }\end{array}$ \\
\hline $\begin{array}{l}\text { Indefinite period } \\
\text { Definite period } \\
\text { Based on a managerial } \\
\text { contract }\end{array}$ & $\begin{array}{l}80.4 \% \\
17.4 \% \\
2.2 \%\end{array}$ & $\begin{array}{l}78.4 \% \\
15.5 \% \\
6.0 \%\end{array}$ & $\begin{array}{l}83.5 \% \\
11.6 \% \\
5.0 \%\end{array}$ & $\begin{array}{l}83.0 \% \\
13.1 \% \\
3.9 \%\end{array}$ & $\begin{array}{l}76.3 \% \\
15.8 \% \\
7.9 \%\end{array}$ \\
\hline
\end{tabular}

$p$ - the probability of chi-square test of independence; - Dependence statistically significant $(\alpha=0.05)$.

Source: own calculations based on empirical data

On the other hand, when it comes to working in a managerial position it is noted that it cannot be clearly indicated what role the modern manager plays. The data allowing assessment of work in a managerial position are shown in the chart below.

\section{Figure 1: The scope of role in a managerial position}

precisely defined role connected with given managerial work, and does not play other roles assigned to other positions in the organization

precisely defined role connected with managerial work, in practice plays many other varied roles in the organization, within a...

defined only overall frames of a managerial role connected with a given position which are to help in real fulfilling roles in the organization
$33.00 \%$

$31.60 \%$ 
Source: own calculations based on empirical data

On the other hand, depending on the characteristics of the organization, it is noted that in the case of industry, work in a managerial position and its specific role have no significant statistical relationship between these variables $(p=0.11)$. Regardless of industry, the employee in a managerial position has a clearly defined role, associated with assigned job, however in practice has many other different roles in the organization, within the scope of others. This role is specific to the following: Production, Industry (42.2\%) and commerce (41.3\%).

On the other hand, when it comes to the volume of employment there is a statistical link between the volume of employment and defining the role of the modern manager in a managerial position $(p=0.01$ with $a=0.05)$. For medium-sized enterprises (50-250 persons), the most characteristic is work in a managerial position, which precisely defines the role related to a given managerial job and the manager does not fulfil any other roles assigned to other positions within the organization (35.2\%). However, in the case of large enterprises, employing over 250 people, characteristic is a precisely defined role, associated with the managerial work; in practice, the manager fulfils many other varied roles in the organization within the scope of other organizational positions (49.3\%).

Regarding decisions about the method and pace of work of a subordinate, the managers in the organization indicate that they are taken by consensus, jointly by the superior and subordinate. Such indication is declared by $63.2 \%$ of respondents. Detailed data appears in the chart below.

Figure 2 Taking decisions regarding the method and pace of work of subordinates by the managers

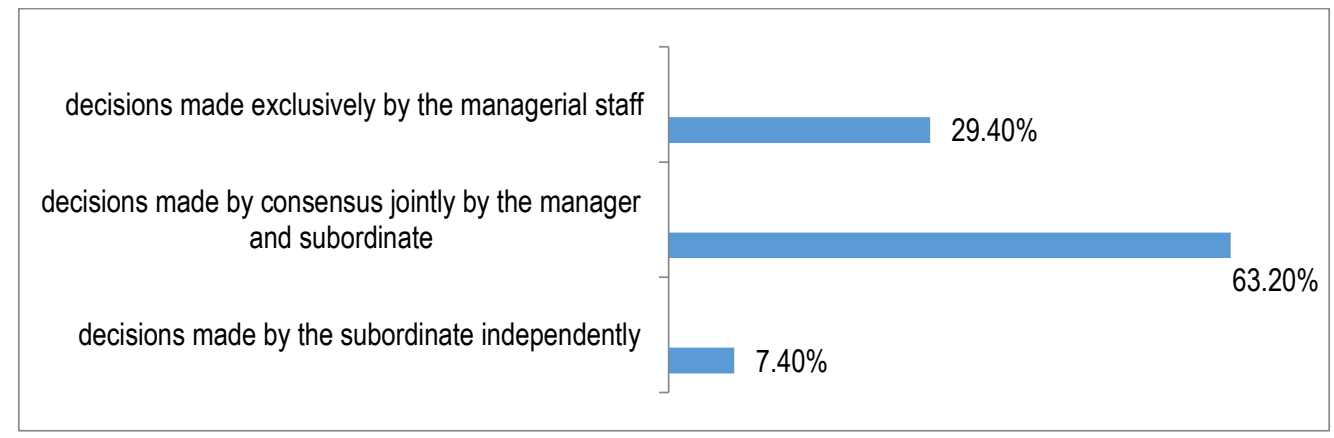

\section{Source: own calculations based on empirical data}

Also subjected to analysis was the relationship between the way of making decisions on the method and pace of work of subordinates by managers in the context of organizational features: the industry and the employment volume. This is shown in Table 2.

Table 2 Type of decision-making regarding the method and pace of work of subordinates by managers against the industry and the employment volume

\begin{tabular}{|l|l|l|l|l|l|}
\hline \multirow{2}{*}{$\begin{array}{l}\text { Type of decision-making } \\
\text { regarding the method and pace } \\
\text { of work of subordinates by } \\
\text { managers }\end{array}$} & \multicolumn{2}{|l|}{ Industry $(p=0.183)$} & \multicolumn{2}{l|}{$\begin{array}{l}\text { Employment volume } \\
(p=0.674)\end{array}$} \\
\cline { 2 - 6 } & Commerce & $\begin{array}{l}\text { Production, } \\
\text { industry }\end{array}$ & Services & $50-250$ persons & $\begin{array}{l}\text { Over } \\
250 \text { persons }\end{array}$ \\
\hline $\begin{array}{l}\text { Decisions made exclusively by the } \\
\text { manager }\end{array}$ & $23.9 \%$ & $31.9 \%$ & $31.4 \%$ & $31.4 \%$ & $26.0 \%$ \\
$\begin{array}{l}\text { Decisions made by consensus } \\
\text { jointly by the manager and } \\
\text { subordinate }\end{array}$ & $65.2 \%$ & $57.8 \%$ & $65.3 \%$ & $61.4 \%$ & $66.2 \%$ \\
\hline
\end{tabular}




\begin{tabular}{|l|l|l|l|l|l|}
$\begin{array}{l}\text { Decisions made by the } \\
\text { subordinate independently }\end{array}$ & $10.9 \%$ & $10.3 \%$ & $3.3 \%$ & $7.2 \%$ & $7.8 \%$ \\
\hline
\end{tabular}

$p$ - the probability of chi-square test of independence; - Dependence statistically significant $(\alpha=0.05)$.

Source: own calculations based on empirical data

The results indicate that there is no relationship between the type of decision-making regarding the method and pace of work of subordinates by managers and the industry and the employment size. Regardless of these qualities, across all industries and regardless of the volume of employment of the surveyed organizations, the managerial staff most often takes decisions by consensus, together with subordinates. Respectively for medium-sized enterprises it is $61.4 \%$, while for large enterprises, employing more than 250 people, it was $66.2 \%$ of the responses obtained. A similar number of indications received also: commerce $(65.2 \%)$, manufacturing and industry $(57.8 \%)$ and services $(65.3 \%)$.

\section{Discussion of results and summary}

Taking into account the obtained results of empirical research it can be noted that managers in Polish organizations are most often employed for an indefinite period. Probably the organization, opting for this form of employment in relation to managers, wants to give them a sense of long-term participation in the organization and a guarantee of security. Thus this form of employment increases the level of loyalty among managers and their organizational commitment.

On the other hand, it limits the flexibility of managers regarding the choice of place and time of work. This is illustrated by the small number of indications concerning the conclusion of employment contracts between the organization and managers under a managerial contract, which is more flexible than a contract of employment resulting from the Labour Code. It also allows greater independence and flexibility in decision-making and makes remuneration conditional on performance.

Whereas referring to the results concerning the absence of a link between the type of employment and industry, and the volume of employment, it is worth noting that they may suggest that today the organization, regardless of its attributes, wants to create the optimal work environment for the manager. One of these elements is the social and physical aspects of the work situation and as part of it - hiring managers for an indefinite period. It is also a remedy for the emigration of skilled managerial staff.

On the other hand, regarding the scope of the role in a managerial position, the role cannot be clearly indicated. Managers have a specific role - from strictly explicit and formalized to the generally defined, bearing the marks of the role which is flexible, dependent on the current situation prevailing in the organization and its environment. Probably it is due to the scope of responsibilities assigned to the given post and due to the conditions offered by the organization. This role depends also on the size of the organization. It is significant that in a medium-sized organization employing 250 people, prevails a role which is precisely defined and associated with a given work and the manager does not perform other roles assigned, for example, to other positions within the organization. This means that the manager focuses solely on his work and does not deal with matters that are not assigned to his position in the organization. This scope of the role is not favourable, because in a situation of adverse developments in the organization, such as fluctuation and absenteeism of staff, there may be a need to perform other roles and functions in the organization. When managers do not have the opportunity to perform other roles in the organization, it may turn that they simply will not be able to fulfil a different role beyond that assigned to a particular position.

In large organizations, however, the managers, although they have a clearly defined role associated with their work, in practice they have many other diverse roles within the scope of other organizational positions. From the perspective of the organization this phenomenon can be considered beneficial, because such a manager is able to fulfil the role assigned not only to his jobs but also other roles within the organizational structure. On the other hand, such a situation from the perspective of the individual may raise some conflicts of roles due to work overload, role ambiguity or contradiction between the expectations of different people. In addition, the realization of a lot of roles by the individual may affect their balance in the context of work-life-balance. 
Regardless of the industry and the size of the organization, the decisions regarding the method and pace of work of the subordinate are taken by supervisors primarily by consensus. This means that in the organization it is symptomatic to make decisions jointly by superiors and subordinates. It can therefore be assumed that these relations are democratic, and such a way of decision-making favours above all the creation of such a work environment that provides subordinates with autonomy and freedom of action and promotes work-based knowledge. An employee in such an environment feels appreciated and needed. The manager must remember, however, that not all decisions should be discussed with subordinates. This applies mainly to strategic decisions.

In organizations, we also have to do with managers who are the so-called autocrats, because almost $1 / 3$ of indications concern just such a situation. This means that decisions are taken only by managers. Probably such behaviour results from the assumption made by managers that subordinates cannot and are not able to make their own decisions about their own work and therefore decisions should be "arbitrarily" imposed on their work. Besides, it seems that the conduct of these managers is related to the belief that the supervisor should give orders to subordinates, because of his role and performed managerial functions.

To conclude, it should be said that the hypothesis is partially confirmed. The role of the manager, and in principle, only its scope, is dependent on the size of the organization. However, no connection between the described role and the industry in which the organization operates was observed. It is very surprising, because it would seem that the industry might affect the implementation of the role of manager. It appears that organizations that belong to the group of Commerce or Industry should be managed in a different way. Perhaps this is due to today's general standards determining how to manage a modern organization.

The conducted study is not without limitations. One limitation is that the study involved only two organizational features: the industry in which the organization operates and its size. Therefore, in-depth studies should be carried out, characterized by heterogeneity of the characteristics of the organization in terms of other attributes, e.g. dimensions that shape the organizational structure or type of organization. Non-profit organizations were not an object of study. It is also important to use more sophisticated statistical techniques.

The conducted research also took into account only certain aspects of the role of the modern manager, such as the type of employment, the scope of the role or the way of decision-making. However, it was not studied, for example, which partial roles are performed by modern manager or what the scope of managerial functions is. Besides it should be noted that the data collected and the conclusions derive from Poland and need not be confirmed in other countries.

These restrictions, however, can become an incentive to undertake further work to better understand the role of the modern manager, which in turn will allow for better adaptation to the specifics of the organization, thus contributing to the efficient and effective management.

\section{References}

[1] Akella D. (2006). Changes in Managerial Work: Tech Managers Dotcom, „Global Business Review”, Vol.7, Issue 2.

[2] Bąk-Grabowska D. (2016). Wielkość zatrudnienia jako czynnik różnicujący stosowanie form zatrudnienia w grupach kapitałowych, Studia Ekonomiczne. Zeszyty Naukowe Uniwersytetu Ekonomicznego w Katowicach, Katowice 2016.

[3] Bednarska-Wnuk I. (2016). Relacje przełożony-podwładny, in: Wielowymiarowa Analiza Zachowań Organizacyjnych [WAZO] w polskich przedsiębiorstwach. Wyniki badań empirycznych, K. Januszkiewicz (ed.), Wydawnictwo Uniwersytetu Łódzkiego, Łódź (In printing).

[4] Bielski M. (2002). Podstawy teorii organizacji i zarządzania, Wydawnictwo C.H. Beck, Warszawa.

[5] Desmarais C., Abord de Chatillon E. (2010). Le rôle de traduction du manager, Entre allégeance et résistance, „Revue française de gestion” No 205.

[6] http://www.hrpolska.pl/kadry/narzedzia/najemnicy-korporacji-kontrakt-na-zarzadzanie, Access 20.08.2016 
[7] Jabłoński M. (2012). Klasycy organizacji a wybrane aspekty zarządzania kompetencjami [in:] B. Mikuła (ed.), Historia i perspektywy nauk o zarządzaniu. Księga pamiątkowa dla uczczenia jubileuszu 40-lecia pracy naukowo-dydaktycznej prof. zw dra hab. Arkadiusza Potockiego, Fundacja Uniwersytetu Ekonomicznego w Krakowie, Kraków.

[8] Januszkiewicz K. (ed.) (2016). Wielowymiarowa Analiza Zachowań Organizacyjnych [WAZO] w polskich przedsiębiorstwach. Wyniki badań empirycznych, Wydawnictwo Uniwersytetu Łódzkiego, Łódź. (In printing)

[9] Katz D., Kahn R. L. (1966), The Social Psychology of Organizations, John Wiley \& Sons, New York.

[10] Lachiewicz S. (2008). Menedżer jako promotor zmian w przedsiębiorstwie, Zeszyty Naukowe Politechniki Łódzkiej, Organizacja i Zarządzanie Nr 49, Łódź.

[11] Mair, J., Thurner, J. (2008). Going global: How middle managers approach the process in medium-sized firms, Strategic Change, 17 (3-4), 83 - 99.

[12] Mintzberg H. (1980). The nature of managerial work, Englewood Clifs, NJ: Prentice Hall.

[13] Nogalski B., Śniadecki J. (2001). Umiejętności menedżerskie w zarządzaniu przedsiębiorstwem, Oficyna Wydawnicza Ośrodka Postępu Organizacyjnego Sp. z 0.0., Bydgoszcz.

[14] Ornarowicz U. (2008). Menedżer XXI wieku: definicja, identyfikacja, edukacja, Szkoła Główna Handlowa, Oficyna Wydawnicza, Warszawa.

[15] Rakowska A. (2007), Kompetencje menedżerskie kadry kierowniczej we współczesnych organizacjach, Wydawnictwo Uniwersytetu Marie-Curie Skłodowskiej, Lublin.

[16] Rouleau, L., Balogun, J. (2011). Middle managers, strategic sensemaking and discursive competence, Journal of Management Studies, 48, 962-965.

[17] Stosik A. (2005), Ewolucja ról menedżerskich w organizacjach entrepreneurskich [in:] J. Skalik (ed.), Zmiana warunkiem sukcesu. Przeobrażenia metod i praktyk zarządzania, Wydawnictwo Akademii Ekonomicznej we Wrocławiu, Wrocław.

[18] Willmott H. (1987). Studying Managerial Work: a critique and a proposal, Journal of Management Studies, Vol. 24, no 3, May. 